\title{
DISCRICIONARIEDADE JUDICIAL E LINGUAGEM JURÍDICO PENAL: OS LIMITES SEMÂNTICOS E JURÍDICOS ENTRE COGNITIVISMO E DECISIONISMO
}

\author{
Ana Carolina Santana ${ }^{1}$ \\ Carlos Alberto Menezes ${ }^{2}$
}

\section{Resumo}

Este artigo se propõe a analisar a discricionariedade judicial na produção das decisões judicias penais. Será utilizada a epistemologia garantista para demonstrar que os pronunciamentos judiciais penais amparados em argumentos puramente ético, morais ou políticos, não passam de mero decisionismo judicial. Será defendida a utilização dos signos linguísticos precisos e determinados como forma de garantir que a semântica legal e a judicial estejam em coerência com a legalidade estrita e a estrita jurisdicionariedade, permitindo o exercício argumentativo de verificação e refutação. Aos naturais espaços de insegurança jurídica este trabalho proporá a aplicação dos princípios gerais como critérios pragmáticos de aceitação.

Palavras-chave: garantismo; cognitivismo; decisionismo; discricionariedade; semântica penal

\section{JUDICIAL DISCRETION AND JURIDICAL LEGAL LANGUAGE: THE SEMANTIC AND LEGAL LIMITS BETWEEN COGNITIVISM AND DECISIONISM}

\begin{abstract}
This article proposes to analyze judicial discretion in the production of criminal judicial decisions. The Guarantor epistemology will be used to demonstrate that criminal judicial pronouncements based on purely ethical, moral or political arguments are mere judicial decision-making. It will be defended the use of precise and determined linguistic signs as a way to ensure that legal and judicial semantics are consistent with strict legality and strict jurisdictionality, allowing the argumentative exercise of verification and refutation. To the natural spaces of legal insecurity this work will propose the application of the general principles as pragmatic criteria of acceptance.
\end{abstract}

Keywords: garantismo; cognitivism; decisionism; discretion; criminal semantics

\section{INTRODUÇÃO}

\footnotetext{
${ }^{1}$ Graduada em Direito pela Universidade Federal de Sergipe; Mestranda em Direito pela Universidade Federal de Sergipe; Juíza de Direito do Tribunal de Justiça do Estado de Pernambuco; Professora convidada da Especialização em Ciências Criminais da Faculdade de Integração do Sertão em Pernambuco.

${ }^{2}$ Doutor em Direito Penal pela Pontifícia Universidade Católica de São Paulo; Professor Adjunto III da Universidade Federal de Sergipe; Advogado.
}

Rev. de Teorias do Direito e Realismo Jurídico | e-ISSN: 2525-9601| Goiânia | v. 5 | n. 1 | p. 86-104| Jan/Jun. 2019 
A percepção que temos dos fatos e acontecimentos é algo subjetivo, não podemos exigir que duas pessoas se comportem da mesma forma ao viver semelhantes desafios e dificuldades. Entretanto, apesar de ser efetivada por pessoas, com diferentes percepções e sentimentos, a atividade científica procura restringir esse subjetivismo e atender a critérios objetivos de produção do conhecimento, utilizando-se para isso de metodologia científica.

$\mathrm{Na}$ ciência jurídica não deve ser diferente. Especificamente na seara penal, os princípios da legalidade e taxatividade enunciam a imposição de limites ao ilimitado exercício de interpretação. E isso se dá diante da evolução científica nessa área. Historicamente, diversos abusos e arbitrariedade foram cometidos por meio do poder punitivo estatal. Nesse sentido, impor limites a esse poder é um dos fatores legitimadores do próprio Estado Democrático de Direito.

Demonstraremos, nesse trabalho, que a diversidade de interpretações dada aos signos linguísticos contidos na legislação penal é diretamente proporcional a elasticidade da semântica legislativa.

Quando há ausência de técnica legislativa, a discricionariedade do poder judicial se transforma em uma fonte inesgotável de arbítrio. Nesse sentido, os argumentos aqui defendidos propõem uma maior cientificidade na produção dos pronunciamentos judiciais, de modo a afastar os decisionismos e voluntarismos jurídicos.

Para tanto, nos utilizaremos da epistemologia garantista, desenvolvida por Luigi Ferrajoli, a qual propõe um método racional e predominantemente objetivo de aplicar a lei ao caso concreto.

Bem verdade que, por se tratar de atividade criativa, a produção dos pronunciamentos judiciais penais, não está completamente divorciada da subjetividade do julgador. E não defenderemos que seja assim.

Será aqui demonstrado que, ainda que a norma penal observe a semântica legislativa enunciada pelo princípio da legalidade estrita e o juiz, ao proceder à verificação fática, utilize a semântica judicial em coerência com a estrita jurisdicionariedade, haverá espaços para a discricionariedade.

Nesse sentido, os espaços de insegurança devem ser reduzidos, mas veremos que se torna impossível excluí-los. Por esta razão, defenderemos a aplicação de critérios 
pragmáticos de aceitação da complementariedade desses espaços por meio da discricionariedade judicial. Esses critérios são controles a esta última, de modo que ela não se confunda com arbitrariedade, consubstanciados em princípios gerais de direito penal.

A aplicação da principiologia possibilita a orientação política das decisões e permite sua valoração, além do seu controle, nos momentos em que se observem espaços de insegurança, ou seja, apenas onde a verdade processual se mostre indeterminada.

\section{EPISTEMOLOGIA GARANTISTA}

Luigi Ferrajoli desenvolve a teoria geral do garantismo como um sistema normativo ideal. Isso significa que esse modelo ideal não será visto, na prática, em sua integralidade, mas a classificação dos sistemas penais é realizada na medida em que estes mais se aproximam ou se afastam desse sistema de norma. Desta feita, será menos autoritário e arbitrário, o sistema penal que mais observe esse modelo normativo.

A racionalidade constante no modelo desenvolvido por Ferrajoli fortalece o Estado de Direito pois tutela a liberdade do cidadão em face ao exercício arbitrário do poder punitivo estatal.

A base fundante do Estado de Direito é a liberdade. "Todo exercício do poder que se afasta dessa base é abuso e não justiça; é poder de fato e não de direito; é uma usurpação e não mais um poder legítimo" (BECCARIA, 2016, p. 23).

Nesse sentido, Ferrajoli desenvolve uma metodologia para produção de pronunciamentos judiciais penais legítimos, que tenham por base a liberdade, limitando o exercício do poder punitivo estatal.

Para tanto, o citado autor divide o poder judicial em quatro. O primeiro deles é o poder de denotação (ou indicação), que se refere à verificação jurídica. Nesse primeiro momento, o julgador é condicionado pela semântica da linguagem legal. Sendo, assim, imprescindível a observância do princípio da legalidade estrita ou taxatividade penal (FERRAJOLI, 2002).

Podemos afirmar que o poder judicial de denotação é o exercício, empreendido pelo julgador, de subsunção do fato à norma, devendo esta última ser suficientemente clara e precisa para a correta efetivação da dedução jurídica.

Rev. de Teorias do Direito e Realismo Jurídico | e-ISSN: 2525-9601| Goiânia | v. 5 | n. 1 | p. 86-104| Jan/Jun. 2019 
O segundo poder judicial que enuncia a racionalidade na construção dos pronunciamentos judicias penais é o poder de comprovação, ou verificação fática. Nesse momento, o julgador condiciona-se pela semântica da linguagem comum. É aqui que são apresentadas as provas empíricas dos fatos penalmente relevantes, realizando-se o exercício de verificação e refutação das teses acusatórias (FERRAJOLI, 2002).

A verificação fática, realizada por meio do poder de comprovação, é o momento de primordial importância para a elaboração da decisão, sendo necessária a construção de regra semântica que assegure a determinabilidade das denotações fáticas.

Isso porque, a ausência de limites legais para análise probatória esvaziaria o caráter objetivo da decisão, transformando-a assim em mero juízo de valor promovedor de decisionismo judicial.

Segundo o modelo garantista, a atividade de verificabilidade fática é cognitiva, de modo que o poder de comprovação deve se expressar em "assertivas empiricamente verificáveis e refutáveis, qualquer atividade punitiva expressamente contrária a este esquema é algo distinto de jurisdição" (FERRAJOLI, 2002, p. 37).

O terceiro poder judicial se expressa através da atividade do juiz de "discernir as conotações que convergem cada fato em diverso dos demais por mais que estes pertençam ao mesmo gênero jurídico" (FERRAJOLI, 2002, p. 34).

Denominado de poder de conotação, ressaltamos que, ainda que possua um caráter objetivo, as conotações nem sempre são predeterminadas legalmente, é nesse momento que o julgador recorre à equidade. No exercício desse poder, na sistemática garantista, cabe ao julgador, por exemplo, excluir responsabilidade ou atenuar penas conforme as especificidades do caso concreto.

Por fim, o quarto e último poder judicial atribuído ao juiz pela epistemologia garantista é o poder de disposição. Nesse último momento de produção das decisões penais é verificada a discricionariedade judicial.

O espaço destinado à atuação deste último poder deve ser reduzido pelos três primeiros, de modo que o juízo se baseie sobre a verdade processual e não sobre valores de outras modalidades cabíveis nesse poder de discricionariedade dispositiva (FERRAJOLI, 2002).

Rev. de Teorias do Direito e Realismo Jurídico | e-ISSN: 2525-9601| Goiânia| v. 5 | n. 1 | p. 86-104| Jan/Jun. 2019 
Os três primeiros poderes - denotação, comprovação e conotação - são inatos à função jurisidicional. Ainda que, de alguma forma, o exercício deles demande a análise de juízos de valor, a sua atividade continua sendo cognitiva, ou seja, verifica-se a existência do fato, a subsunção deste fato à norma penal proibitiva e, analisa-se as especificidades do caso concreto.

Por sua vez, "o poder de disposição é sempre o produto de carências ou imperfeições do sistema e como tal é patológico e está em contradição com a natureza da jurisdição" (FERRAJOLI, 2002, p. 134).

Nesse sentido, o exercício do poder de disposição é diretamente proporcional aos espaços de insegurança os outros três poderes judiciais, de modo que o poder de disposição será absoluto quando a insegurança for total.

Essa insegurança se refere à indeterminabilidade de decisão acerca da verdade processual, ou seja, é a ausência de técnicas apropriadas de formulação e aplicação das leis aos fatos julgados (FERRAJOLI, 2002). Essas técnicas podem estar previstas expressamente na legislação ou se apresentarem principiologicamente enquanto regras de julgamento.

Um clássico exemplo contido na legislação brasileira acerca da citada insegurança é o termo "ordem pública", previsto no art. 312 do Código de Processo Penal como circunstância autorizadora da decretação de prisão preventiva.

Não há, na legislação, nenhuma norma de delimitação da vagueza do citado termo e a principiologia não demonstra claramente qualquer restrição à sua aplicação. Apesar do ordenamento jurídico brasileiro enunciar a liberdade enquanto regra e a prisão como exceção, isso não impede o exercício absoluto do poder de disposição nas decisões judiciais de decretação de prisão preventiva fundamentadas na garantia da ordem pública.

A epistemologia garantista desenvolve um modelo ideal a ser perseguido, mas consciente de que não será alcançado, diante desse caráter próprio de idealismo. Entretanto, quanto mais nos aproximamos dele, fortalecemos o Estado de Direito, pois reduzimos a discricionariedade judicial e reforçamos o princípio da legalidade e segurança jurídica.

Bem verdade que os críticos da teoria do garantismo penal acreditam que a racionalidade apresentada por esse sistema normativo engessaria a atividade judicial, retomando o pensamento de Beccaria (2016, p. 25) quando afirma que "o juiz deve fazer um silogismo perfeito", cabendo a ele tão somente confirmar um fato.

Rev. de Teorias do Direito e Realismo Jurídico | e-ISSN: 2525-9601| Goiânia | v. 5 | n. 1 | p. 86-104| Jan/Jun. 2019 
Não se trata disso. Esclarecemos que o sistema normativo de garantias busca reduzir a aplicação dos valores substanciais do julgador, sejam eles extra ou metajurídicos, denominados por Ferrajoli (2002) de valores políticos ou éticos-políticos.

Conforme já explicado, à medida que são apresentadas incertezas nos três primeiros poderes judiciais, que são essencialmente cognitivos, abre-se espaço ao poder de discricionariedade dispositiva, consequentemente é aberto também o espaço para decisionismos judiciais, ou seja, produção de decisões amparadas em substancialismo penal, incapazes de ser verificadas e refutadas racionalmente.

Desta feita, a redutibilidade ou irredutibilidade dos espaços para a disposição judicial está ligada à teoria da linguagem. Desde a produção legislativa até a interpretação das leis, é exigida objetividade no emprego dos termos legais e sentidos interpretativos. Para isso, é necessária a introdução de regras semânticas tanto de formação da linguagem legal quanto de formação da linguagem jurisdicional.

\section{HETEROINTEGRAÇÃO DA LINGUAGEM PENAL}

Delimitado o campo de atuação dos quatro poderes judiciais necessários à produção das decisões penais, segundo a epistemologia garantista, cabe agora analisar de que forma a semântica interfere no exercício desses poderes. Fixaremos assim, neste item, os limites entre a verificação e a valoração empreendidas pelo poder punitivo estatal.

A validade das normas no Estado Constitucional de Direito e, ao mesmo tempo a relação entre democracia política (ou formal) e democracia substancial se reflete no fortalecimento do papel da jurisdição e em uma nova e mais forte legitimação democrática do poder judicial e de sua independência. Desse modo, cabe ao Poder Judiciário, através do exercício da jurisdição, a função de garantia do cidadão frente às violações de qualquer nível da legalidade por parte dos poderes públicos (FERRAJOLI, 2016).

Para tanto, as decisões judiciais devem se amparar no cognitivismo, possibilitando o exercício de verificabilidade e refutabilidade dos argumentos nela contidos. Para o modelo do garantismo cognitivista, é necessária a certeza e clareza dos signos linguísticos contidos na lei e, consequentemente, na interpretação judicial deles.

Rev. de Teorias do Direito e Realismo Jurídico | e-ISSN: 2525-9601| Goiânia | v. 5 | n. 1 | p. 86-104| Jan/Jun. 2019 
O primeiro momento para delimitar a clareza dos significados das palavras é o da produção legislativa. Obedecendo ao princípio da legalidade estrita, o legislador deve se utilizar de definições precisas, contrariamente, a utilização das previsões de figuras indeterminadas viola flagrantemente o princípio citado.

Normas que são produzidas respeitando a separação entre direito e outros critérios extrajurídicos de qualificação ou valoração observam o convencionalismo penal. Isso porque, segundo o sistema garantista, quanto mais uma legislação se utilize de critérios ontológicos para determinar as figuras delitivas mais ela se aproxima do substancialismo penal.

Sabemos que o substancialismo penal não se coaduna com o Estado Constitucional de Direito uma vez que esvazia o princípio da legalidade estrita, deixando ao livre arbítrio judicial a decisão acerca das condutas criminosas e seus autores.

A título de exemplo, o substancialismo penal foi empregado na doutrina nazista, do "direito penal da vontade" ou do "tipo de autor" e na stalinista do "inimigo do povo", e ainda na concepção positivista antropológica do "delinquente natural” (FERRAJOLI, 2002).

Dessa forma, somente através de signos linguísticos determinados, claros e precisos, será possível proceder à verificabilidade e à falseabilidade dos argumentos sem o predomínio da utilização de juízos de valor no exercício dos poderes judiciais de denotação e de comprovação.

Se aplicarmos a teoria do significado à linguagem penal, "diremos que uma tese judicial é verificável e falseável se (e apenas se) os termos nela empregados forem providos de extensão determinada" (FERRAJOLI, 2002, p. 98). Considerando ainda que, na seara penal, a extensão é determinada pela intenção, não basta apenas a determinabilidade daquela primeira, uma vez que suas intenções também devem estar devidamente definidas.

Nesse sentido, Ferrajoli (2002) afirma que a verificabilidade jurídica deve estar condicionada pela semântica da linguagem legal, enquanto que a verficabilidade fática deve ser condicionada pela semântica da linguagem comum. Isso significa que o primeiro poder judicial exercido na produção da decisão penal, ou seja, o poder de denotação, somente é corretamente efetivado se os conceitos penais forem suficientemente claros para permitir a subsunção judicial de fatos empíricos exatamente determinados (FERRAJOLI, 2002).

Podemos afirmar que a verificabilidade jurídica somente é possível se o legislador observar o princípio da legalidade estrita e da taxatividade penal, confeccionando leis 
precisas, com extensão determinada. As palavras utilizadas na legislação não podem ser vagas nem valorativas, apenas a título de exemplificação, na legislação brasileira continha a expressão "mulher honesta" como elemento normativo de tipo penal. Torna-se, assim, impossível realizar verificabilidade e falseabilidade na decisão que emprega termos vagos, uma vez que sua interpretação exige tão somente a valoração (ético, moral, política) do julgador acerca do seu significado.

É necessário rigor semântico na linguagem legislativa. O legislador deve respeitar a legalidade estrita e, consequentemente, o convencionalismo penal, somente assim é possível a precisão no exercício de conotação legal.

No segundo momento, o de verificabilidade fática, através da efetivação do poder judicial de comprovação, é necessária uma regra semântica de formação da linguagem judicial, que assegure a determinação e precisão nas denotações fáticas.

Nesse momento, é exercida a estrita jurisdicionariedade, a qual exige uma série de regras "da verificabilidade e da refutabilidade das teses que no processo enunciam os fatos e as provas, que tanto aquelas quanto estas sejam individualizadas mediante descrições precisas e sem o uso de palavras vagas ou valorativas" (FERRAJOLI, 2002, p. 101).

Ainda segundo Ferrajoli (2002), a utilização das palavras equivocadas, seja na lei para descrever os fatos imputados, seja no juízo de valor acerca da realização das provas, representa o esvaziamento das garantias penais. Esse esvaziamento é feito pelo julgador que, no momento da verificabilidade fática, se utiliza de inclinações pessoais, valorações próprias, prognoses de periculosidade, amparadas na indeterminabilidade da denotação jurídica.

Assim, o pronunciamento judicial penal não passa de mero decisionismo do juiz, que pode mudar completamente seu entendimento no julgamento de outro caso ainda que semelhante.

Por isso, Ferrajoli (2002) fala em uma heterointegração da linguagem penal. Uma vez que o poder de denotação jurídica exige a interpretação da lei, enquanto que o poder de denotação fática (comprovação) exige a interpretação dos fatos, necessitamos de determinação e clareza tanto na linguagem legal quanto na linguagem judicial, esta última advinha da linguagem comum.

Por isso, afirmamos que as regras semânticas, ligadas a esses dois primeiros poderes judiciais, são complementares. A legalidade estrita, dirigida ao legislador, é 
complementar à estrita jurisdicionariedade, que é dirigida ao julgador, de modo que, tanto numa quanto na outra, a definição dos signos linguísticos deve ser clara e precisa.

Apesar do desenvolvimento dessas regras e da enunciação de princípios que vedam o arbítrio judicial através do exercício interpretativo, ainda se percebe, na prática judicial, operações pouco técnicas "de sub-reptícias redefinições descritivas e matizadoras, associadas às qualificações jurídicas para determinar empiricamente sua denotação fática" (FERRAJOLI, 2002, p. 103), ou seja, de ressignificação dos termos legais para que seja possível a subsunção dos fatos julgados; além de "sub-reptícios juízos de valor, associados à descrição dos fatos para derivar analiticamente sua denotação jurídica" (FERRAJOLI, 2002, p. 103), isso quer dizer que o julgador utilizando-se do seu livre convencimento emprega interpretação que lhe seja conveniente para fins de subsunção.

Observamos que essas redefinições promovidas pelo julgador aumentam consideravelmente a polissemia e redundância do vocabulário jurídico. No ordenamento jurídico brasileiro, podemos citar novamente, para ilustrar essa polissemia, o termo "ordem pública", que é empregado por alguns julgadores como caracterizador da "credibilidade da justiça" que, de igual forma, não possui precisão, sendo redundante e indeterminado se mostra como fonte de arbítrio judicial.

Desse modo, prisões preventivas são decretadas através de decisões de ressignificação, provindas da conveniência de cada julgador, utilizando-se apenas de juízos de valor, de inferências pessoais, uma vez que não há qualquer critério objetivo, nem legal, nem principiológico, para proceder à aplicação desse signo linguístico.

Por fim, percebemos que Ferrajoli (2002) distingue o poder de denotação em duas análises, a denotação jurídica que é a interpretação da lei, e a denotação fática que é, por sua vez, a interpretação dos fatos. Nesse sentido, a irracionalidade e ilegitimidade das decisões é variável conforme a indeterminabilidade semântica da linguagem penal. O grau dessa indeterminabilidade é diretamente proporcional à ineficácia do sistema de garantias penais.

\section{DISCRICIONARIEDADE JUDICIAL}

Conforme visto no item anterior, o poder de denotação do julgador é utilizado para “integrar os espaços irredutíveis de discricionariedade deixados em aberto pelos defeitos

Rev. de Teorias do Direito e Realismo Jurídico | e-ISSN: 2525-9601| Goiânia | v. 5 | n. 1 | p. 86-104| Jan/Jun. 2019 
inevitáveis de denotação da linguagem legal e da linguagem comum" (FERRAJOLI, 2002, p. 104).

No campo da linguagem legal é utilizada a interpretação da lei para integrar os espaços irredutíveis contidos nos signos linguísticos legislativos. Enquanto que, no campo da linguagem comum, é feita a interpretação dos fatos de modo a possibilitar a denotação fática mais objetiva e precisa possível.

Por sua vez, o último poder enunciado pelo modelo garantista é o poder judicial de disposição. Esse poder é utilizado quando os princípios da legalidade estrita e de estrita jurisdicionariedade forem ausentes, permitindo que o julgador profira decisões discricionárias não sobre a verdade, conforme exigido pela denotação fática, mas sobre valores outros, do tipo ético-político (FERRAJOLI, 2002).

Nesse sentido, quando não se consegue determinar a verdade, é instaurado o arbítrio judicial. Isso porque, todos os espaços de insegurança são equivalentes a espaços de poder.

O poder judicial de disposição dispensa a motivação cognitiva pois se utiliza apenas de opções ou juízos de valor que não contém caracterização semântica, mas apenas caracterizações pragmáticas (FERRAJOLI, 2002).

Percebemos aqui que o sistema normativo garantista, desenvolvido por Luigi Ferrajoli, defende que quanto maior o exercício do poder judicial de disposição menos se observa a efetividade da jurisdição. Isso porque, a decisão judicial que não possibilita a refutação objetiva é mero exercício de repressão, uma vez que não existe o juízo de comprovação e sim de decisão. É o puro poder das instâncias julgadoras (FERRAJOLI, 2002).

Entretanto, os limites à discricionariedade judicial é questão há muito analisada e debatida por diversos autores.

$\mathrm{O}$ ordenamento jurídico como sistema foi defendido por Norberto Bobbio, que enunciou a existência da norma fundamental como pressuposto para a unidade desse sistema. A referida norma teria a possibilidade de relacionar-se, direta ou indiretamente, com todas as normas do ordenamento jurídico (BOBBIO, 1995).

A coerência desse sistema de norma proposto por Bobbio se fundamenta, atualmente, no paradigma da democracia constitucional. De modo que, toda e qualquer norma 
deve respeitar a Constituição, seja na sua elaboração ou na sua interpretação. Não podendo se afastar dos direitos fundamentais, no caso aqui analisado, mais especificamente das garantias penais constitucionalmente previstas.

Os problemas oriundos da discricionariedade judicial não atingem somente a seara penal, mas é neste campo que suas consequências são mais nefastas. Não são poucos os momentos nos quais o julgador substitui a razão por sua própria vontade, transmudando a relação entre norma e sentença, que passa a assumir aspecto diverso, o caso concreto é decidido conforme a vontade do juiz e não amparado na racionalidade das leis da lógica (LOSANO, 2010).

Considerando que "toda interpretação é um ato produtivo; sabemos que o intérprete atribui sentido a um texto e não reproduz sentidos nele já existentes" (STRECK, 2017, p. 71). Dessa forma, não defendemos a ausência da atividade interpretativa, de criação, mas sim a possibilidade de um efetivo controle hermenêutico do produto, ou seja, dos pronunciamentos judiciais.

Sobre essa atividade criativa do juiz, Hart (2009) apresentou a tese de que o direito possuía um espaço de "textura aberta", no qual o julgador cria uma regulação para o caso, considerando que antes daquela decisão não havia solução respaldada no Direito da comunidade política.

Por sua vez, Dworkin (2016) enunciou que, quando empregada em seu sentido forte $^{3}$, a discricionariedade se traduz na impossibilidade da decisão judicial ser conduzida por um padrão antecipadamente estabelecido. Desta feita, quando o julgador utiliza seu poder discricionário não se pode dizer que ele está vinculado a padrões, mas apenas aferir quais padrões que ele empregou.

Gadamer (1999) analisando que é o intérprete que atribui sentido ao texto, defendeu que a interpretação da lei não pode ser tida como uma tradução arbitrária. Isso porque, quando o juiz aplica a lei ao caso concreto procura adequá-la às necessidades atuais, para resolver a tarefa prática.

Ainda segundo este último autor, compreender é aplicar. Desta feita, "se o intérprete é incapaz de compreender o sentido democrático de um texto, a norma que ele irá produzir terá conteúdo antidemocrático" (CASARA, 2017, p.74)

\footnotetext{
${ }^{3}$ Dworkin elenca três sentidos para o termo "discricionariedade", sentido limitado, fraco e forte. 
O próprio Hans Kelsen (2006) referiu-se a esse espaço de conformação do juiz, enquanto órgão aplicador da norma, no âmbito da "moldura da norma".

Nesse sentido, entendemos que o exercício da discricionariedade judicial sem regras de limitação gera arbítrio e a decisão perde sua legitimidade uma vez que se transforma em mero instrumento de repressão.

Não se nega a possibilidade de que argumentos morais integrem o Direito, isso porque, enquanto linguagem, este último possui vaguezas e ambiguidades, que são os espaços de insegurança. Desse modo, se não há uma definição acerca de sua significação, os julgadores estão autorizados a criar o Direito fazendo uso de padrões externos ao Direito, ou seja, extrajurídicos, sejam morais, éticos ou políticos (STRECK, 2017).

Desta feita, nos casos em que há uma "textura aberta" da linguagem jurídica, seria possível a interpretação do Direito, pelo julgador, de forma discricionária (HART, 2009). Entretanto, na prática jurídica, essa discricionariedade judicial "assemelha-se à vulgata da filosofia da consciência, ao modo como o subjetivismo da modernidade compreende a própria realidade, ou seja, sem nenhum controle intersubjetivo" (STRECK, 2017, p. 57).

Defendemos, neste trabalho, a impossibilidade de excluir a discricionariedade judicial, uma vez que a aplicação da lei, através do exercício interpretativo, se dá de forma criativa. Entretanto, a análise jurídico-penal não deve ser pautada em representações, ressignificações linguísticas, conforme a particularidade de cada julgador, mas sim em critérios rigorosos de coerência e inteligibilidade (PUNTEL, 2015).

Esclarecemos, assim, que não se trata de mecanizar o direito e, consequentemente o exercício interpretativo de sua aplicação. Mas sim de limitar e restringir as interpretações amparadas em critérios outros, extrajurídicos, sejam eles morais, éticos ou políticos, principalmente na produção de pronunciamentos judiciais penais.

\section{CRITÉRIOS PRAGMÁTICOS DE ACEITAÇÃO}

Conforme já explicitado, compreendemos ser impossível obter a perfeita neutralidade do julgador na interpretação da lei e aplicação do direito. Entretanto, diante da possibilidade de arbítrios, cometidos através do decisionismo judicial, é necessário desenvolver um meio de controle cognitivo do exercício do poder judicial de disposição.

Rev. de Teorias do Direito e Realismo Jurídico | e-ISSN: 2525-9601| Goiânia| v. 5 | n. 1 | p. 86-104| Jan/Jun. 2019 
Quando se diz que a discricionariedade judicial gera o arbítrio, materializado no decisionismo judicial, é justamente porque não há qualquer espécie de controle conteudístico, em nenhum deles (STRECK, 2017).

Isso porque, as decisões amparadas em critérios outros, que não sejam jurídicos, não deixam de ser motivadas, ainda que a motivação não se utilize de argumentos cognitivos, o que impossibilita a verificação e refutação, há motivação nos juízos de valor.

Ocorre que, "os juízos de valor são suscetíveis de argumentação e de controle conforme critérios pragmáticos de aceitação" (FERRAJOLI, 2002, p. 138). Referidos critérios citados pelo autor são os princípios gerais do ordenamento. Dessa forma, podemos afirmar que o controle das decisões, quando houver espaços de insegurança na comprovação jurídica e fática, será feito através de princípios políticos expressamente previstos na Constituição e nas leis, ou ainda, extraíveis da doutrina jurídico-penal.

Considerando que nenhum sistema normativo será fechado, é exigência contínua do seu funcionamento, regular e prático, as heterointegrações que deverão ser realizadas no exercício de autonomia e discricionariedade do intérprete (FERRAJOLI, 2002).

Desta feita, a escolha feita no âmbito de inexatidão do signo linguístico, ou seja, do espaço de insegurança da norma, representa uma decisão extrajurídica do juiz, por isso não podemos falar em neutralidade moral, ética ou política deste último.

Para que essas decisões extrajurídicas não incorram em arbítrio judicial, é construído um sistema de critérios de controle, conforme já explanado, consistente na aplicação dos princípios gerais. Entretanto, na prática, esse sistema não possui a capacidade de vinculação. Ainda assim, é importante defende-lo enquanto modelo ideal de limitação do arbítrio judicial, enunciando que os pronunciamentos judiciais penais que mais o observam são também os mais cognitivistas e menos decisionistas.

Referidos princípios são verificáveis no ordenamento em seus diversos momentos, existem princípios que orientam a decisão quanto à verificação jurídica, quando a linguagem legal não observa a estrita legalidade; outros que orientam a decisão quanto à verificação fática, quando há incertezas acerca da verdade processual; outros ainda enunciam o exercício do poder equitativo.

Podemos exemplificar com a regra de julgamento do in dubio pro reo, construída doutrinariamente como corolário do princípio constitucional da presunção de inocência. Nesse 
sentido, havendo espaços de incerteza quanto ao cometimento do delito ou quanto à sua autoria, após a fase de verificação e refutação fática, ou seja, após a instrução probatória, cabe ao julgador aplicar o in dubio pro reo.

É necessário observar que essa aplicação independe de um juízo de valor do julgador. De modo que não é aplicável, nesse momento, a análise pessoal do juiz acerca da concordância ou discordância com o citado princípio. Cabe apenas aplicá-lo, por se tratar de regra de julgamento para os casos de dúvida.

Ainda analisando o exemplo citado, percebemos que, equivocadamente, construiu-se um entendimento jurisprudencial no qual a dúvida, na primeira fase do procedimento do Tribunal do Júri, autorizaria a pronúncia do acusado, em amplo desacordo não somente com a regra de julgamento analisada, mas também com o expressamente previsto no art. 414 do código de processo penal.

São nessas construções, divorciadas do espírito constitucional e amparada tão somente em argumentos ético e morais, que reside o decisionismo judicial e, consequentemente, o perigosismo para a segurança e harmonia do ordenamento jurídico. No caso analisado, não há o afastamento apenas do princípio constitucional, mas também da regra jurídica contida na legislação que regulamenta o procedimento.

Desse modo, apesar desses princípios gerais não possuírem forma vinculativa, não custa lembrar que a sua riqueza no ordenamento "está determinada não apenas pelos valores de justiça substancial por eles incorporados no plano legal, mas também pelo trabalho científico e jurisprudencial realizado sobre eles pelos juristas" (FERRAJOLI, 2020, p. 139). Os princípios gerais do direito devem nortear a atuação do julgador, e este não pode preteri-lo por livre convencimento motivado.

Entendemos que o Direito, enquanto ciência, deve possuir método. E esse entendimento não excepciona o produto da ciência do direito, ou seja, a aplicação da lei ao caso concreto através da produção da decisão judicial. O julgador deve se utilizar de racionalidade e inteligibilidade para fundamentar suas decisões, de modo que elas possam ser refutações logicamente, por meio do exercício de verificabilidade e falseabilidade. Decisões amparadas em meros discursos morais, éticos ou políticos não podem ser objeto do citado exercício.

\section{CONCLUSÃO}

Rev. de Teorias do Direito e Realismo Jurídico | e-ISSN: 2525-9601| Goiânia | v. 5 | n. 1 | p. 86-104| Jan/Jun. 2019 
Demonstramos, nesse trabalho, que apesar da atividade judicial ser uma atividade criativa, isso não autoriza que, em nome do livre convencimento motivado, o julgador se utilize de argumentos puramente éticos, morais e políticos.

Enquanto ciência, o Direito deve possuir metodologia para nortear as produções deles advinhas, a exemplo dos pronunciamentos judicias e, no caso aqui analisado, mais especificamente dos penais. Referida metodologia, no ordenamento jurídico brasileiro, possui fundamento na Constituição Federal, que enumera os direitos e garantias dos investigados e dos acusados.

Nesse sentido, analisamos que a função legislativa tem contribuição direta para a racionalização do sistema. Isso porque, o princípio da estrita legalidade prevê que os preceitos legislativos, ou seja, o conteúdo da norma deve ser suficientemente determinado, respeitando o axioma "nullun crimen, nulla poena sine legi scripta". Ressaltamos ainda que é insuficiente a previsibilidade apenas gramatical, sendo necessária também a previsibilidade conteudística.

Uma vez observado o princípio da estrita legalidade, pelo legislador, cabe ao julgador, ao aplicar a lei ao caso concreto, utilizar-se também de signos linguísticos determinados, de modo que seja possível o exercício de verificação e refutação da decisão judicial. Assim agindo, o julgador observa a jurisidicionariedade estrita.

Do contrário, não havendo a estrita legalidade e a jurisidicionariedade estrita, ocorrerá o decisionismo judicial, que não possui qualquer compromisso com a convencionalismo penal, mas sim com o substancialismo penal, tão rechaçado em todos os ordenamentos jurídicos ocidentais pós segunda guerra.

A decisão judicial fundamentada no direito penal do autor, na qual não há exercício de verificabilidade/falseabilidade é incompatível com o Estado de Direito. Um dos exemplos demonstrados nesse trabalho que ilustra essa questão é a previsão do signo linguístico "ordem pública" para autorizar a restrição de liberdade através da decretação de prisão preventiva.

Considerando que não há qualquer limite técnico jurídico objetivo, que possibilite o exercício de verificação e refutação da análise judicial, o termo “ordem pública" é utilizado em descompasso com o ordenamento jurídico. Isso porque possibilita a aplicação de uma exceção constitucional, a prisão, utilizando-se de arbitrariedade judicial, a exemplo dos 
julgadores que se utilizam do termo para decretar prisões preventivas fundamentados na necessidade de manter a credibilidade da justiça.

Desse modo, ainda que a decisão judicial tenha seus espaços naturais de incerteza, uma vez que a lei não dispõe de meios para prever todas as situações fático jurídicas possíveis, não é legítimo que a discricionariedade se torne arbitrariedade judicial. Assim, apesar de reconhecermos o caráter político da função judicial, entendemos que os citados espaços de incerteza não podem ser preenchidos através de critérios subjetivos de justiça substancial.

A técnica jurídica não permite que a fundamentação se restrinja ao próprio sentido formal de fundamentar, é necessário que o conteúdo seja coerente com a Constituição Federal e os preceitos legais. O livre convencimento motivado não autoriza ao julgador proceder livremente à argumentação ética e moral que o orienta pessoalmente. Conforme vimos, esse fato foi predominante em um dos momentos históricos mais sombrios do mundo, ainda que amparado legalmente.

Não se pode conceber que a liberdade do julgador para motivar suas decisões seja interpretada em dissonância com a Constituição Federal. É imprescindível a utilização de técnica jurídica, de metodologia, de observância aos princípios gerais para que a atividade de produção da decisão esteja amparada no cognitivismo e não no decisionismo.

Contudo, apesar da delimitação objetiva da linguagem, através da técnica legislativa, é possível que, na análise do caso concreto, haja incerteza insolúvel no plano cognitivo, seja na subsunção do fato à norma, ou na própria análise probatória. Para tanto, defendemos a utilização dos princípios gerais do direito como critério de orientação da discricionariedade judicial.

Os princípios gerais do direito são, doutrinariamente, orientações que corroboram com a coerência do sistema quando há espaços de incerteza na produção da decisão. A exemplo da regra de julgamento consubstanciada no in dubio pro reo, que advém do princípio constitucional da presunção de inocência.

Quanto à aplicação desta regra de julgamento não cabe ao juiz qualquer análise acerca de sua justeza ou não, mas sim aplica-la. O decisionismo, hoje visto em grande atuação no país, pauta-se nesse tipo de análise judicial, individual, ética, moral e política, acerca da 
concordância pessoal do magistrado com a principiologia adotada pela Constituição Federal e pelo ordenamento jurídico brasileiro.

Nesse sentido, foi demonstrado que referidos princípios gerais do direito orientam politicamente as decisões judiciais, permitindo sua valoração e controle, informando valores de justiça substancial, incorporados no plano legal, que possibilitam o trabalho científico e jurisprudencial a ser realizado pelo jurista e aplicador do direito. Defendemos que, apesar de não vinculantes, devem ser observados pelos julgadores pois é necessário para a segurança jurídica e manutenção da coerência constitucional.

Dessa forma, os citados princípios, enquanto construções advindas do ordenamento jurídico, não devem ser ressignificados através do uso da discricionariedade judicial. De modo que não se pode interpretar um princípio geral de direito penal motivando-o em juízos de valor contraditórios com o sentido doutrinário e histórico que ele possua.

Concluímos que, a manutenção do ordenamento jurídico democrático, enquanto Estado de Direito, exige racionalidade e inteligibilidade nos pronunciamentos judicias penais e, para isso, deve ser utilizada a metodologia garantista limitadora do poder punitivo estatal e controladora do arbítrio judicial. 


\section{REFERÊNCIAS}

BECCARIA, Cesare. Dos Delitos e das Penas. Edição especial. São Paulo. Editora Nova Fronteira, 2016.

BOBBIO, Norberto. Teoria do ordenamento jurídico. 10ª Edição. Brasília. Editora Universidade de Brasília, 2006

FERRAJOLI, Luigi. Direito e razão: teoria do garantismo penal. $3^{\text {a }}$ edição. São Paulo. Editora Revista dos Tribunais, 2002.

Editora Trotta, 2016.

Derechos y garantias penais: la lei del más débil. $8^{a}$ edição. Madrid.

CASARA, Rubens R. R. Estado Pós Democrático: neo-obscurantismo e gestão dos indesejáveis. 1 ${ }^{\mathrm{a}}$ edição. Rio de Janeiro. Editora Civilização Brasileira, 2017.

DWORKIN, Ronald. Levando os direitos a sério. $3^{\text {a }}$ edição. São Paulo. Editora Martins Fontes, 2010.

GADAMER, Hans-George. Verdade e Método. $3^{\text {a }}$ edição. Petrópolis. Editora Vozes, 1999.

HART, Herbert L. A.. O conceito de Direito. $1^{\text {a }}$ edição. São Paulo. Editora Martins Fontes, 2009.

KELSEN, Hans. Teoria Pura do Direito. $8^{\text {a }}$ edição. São Paulo. Editora Martins Fontes, 2009.

LOSANO, Mario G. Sistema e Estrutura no Direito. $1^{a}$ edição. São Paulo. Editora Martins Fontes, 2010.

PUNTEL, Lorenz. A filosofia como discurso sistemático. $1^{\text {a }}$ edição. São Leopoldo. Editora Unisinos, 2015.

STRECK, Lenio Luiz. Verdade e Consenso. 6 6 edição. São Paulo. Editora Saraiva, 2017.

Rev. de Teorias do Direito e Realismo Jurídico| e-ISSN: 2525-9601| Goiânia| v. 5 | n. 1 | p. 86-104| 
